\title{
A Case Study of Albania's Participation in PISA 2009
}

Alfons Harizaj $^{1}$

$\approx$ The paper presents a view of the results and progress of Albania in the Programme for International Students' Assessments 2009 (PISA 2009). The overall goal and objectives of PISA are to offer support and expertise in the field of the evaluation of educational development factors in Albania. One of the methods successfully used for monitoring the achieved progress during the given study period was the estimation and comparison of results with the results of previous PISA participations. A broader comparison of these statistics with those of other PISA participants in the Albanian region provides a real picture of the situation, showing the progress Albania has made and indicating how effective Albania's educational policies are.

Keywords: Gender differences, Learning outcomes, Main domain in PISA, PISA assessments, Student performance, The socioeconomic environment,

\section{Introduction}

Since 1990, changes and reforms have been implemented in the Albanian education system. One important reform was a new evaluation system for primary school and high school through national exams. Such exams are standardised and are performed all over the country at the end of primary and high school education. As the most important international assessment institution, PISA assessment participation makes a contribution to, and is part of, Albanian system reforms.

At the end of primary education (nine-year education), all Albanian students sit two exams in Albanian language and mathematics. The comparison of these two final course results with students' results in PISA international assessment has been useful and important in interpreting and analysing

$1 \quad$ National Agency of Exams

alfonsharizaj@yahoo.com 
achievements, and even more so in evaluating the effect of changes undertaken in students' education at primary school level.

Albania has participated in PISA 2000 and PISA 2009, and will again be one of the participants in PISA 2012.

\section{Participating countries and Albanian participation in PISA 2009}

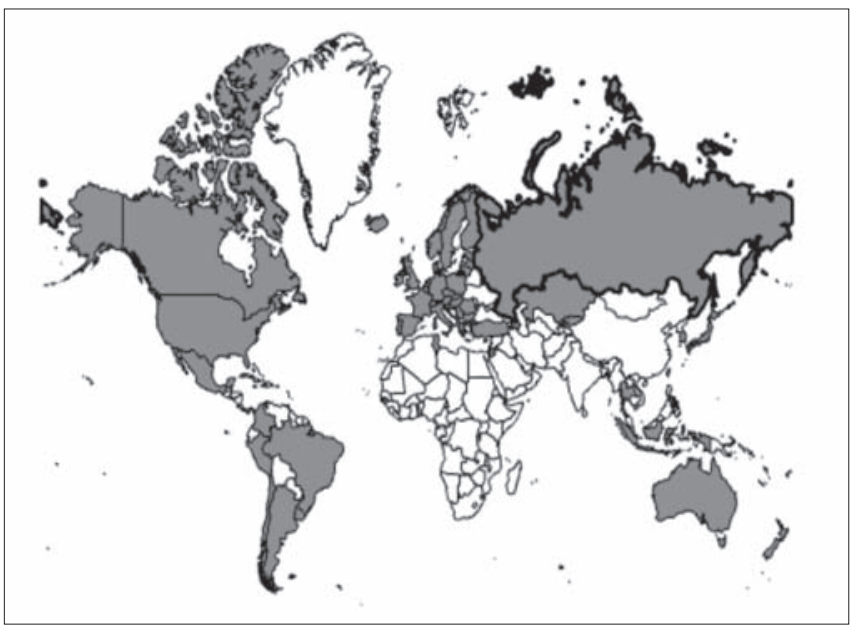

Figure 1: Map of countries participating in PISA 2009.

Countries participating in PISA 2009 - OECD (Organisation for Economic Co-operation and Development) countries are:

$\begin{array}{llllll}\text { 1. } & \text { Australia } & \text { 13. } & \text { Hungary } & 25 . & \text { Poland } \\ \text { 2. } & \text { Austria } & 14 . & \text { Iceland } & 26 . & \text { Portugal } \\ \text { 3. } & \text { Belgium } & 15 . & \text { Ireland } & 27 . & \text { Slovak Republic } \\ \text { 4. } & \text { Canada } & 16 . & \text { Israel } & 28 . & \text { Slovenia } \\ \text { 5. } & \text { Chile } & 17 . & \text { Italy } & 29 . & \text { Spain } \\ \text { 6. } & \text { Czech Republic } & 18 . & \text { Japan } & 30 . & \text { Sweden } \\ \text { 7. } & \text { Denmark } & 19 . & \text { Korea } & 31 . & \text { Switzerland } \\ \text { 8. } & \text { Estonia } & 20 . & \text { Luxembourg } & 32 . & \text { Turkey } \\ \text { 9. } & \text { Finland } & 21 . & \text { Mexico } & 33 . & \text { United Kingdom } \\ \text { 10. } & \text { France } & 22 . & \text { Netherlands } & 34 . & \text { United States } \\ \text { 11. } & \text { Germany } & 23 . & \text { New Zealand } & & \\ \text { 12. } & \text { Greece } & 24 . & \text { Norway } & & \end{array}$


Countries participating in PISA 2009 - partner countries/economies are:

$\begin{array}{llllll}\text { 1. } & \text { Albania } & \text { 11. } & \text { Indonesia } & 22 . & \text { Qatar } \\ \text { 2. } & \text { Argentina } & \text { 12. } & \text { Jordan } & 23 . & \text { Romania } \\ \text { 3. } & \text { Azerbaijan } & 13 . & \text { Kazakhstan } & 24 . & \text { Russian Federation } \\ \text { 4. } & \text { Brazil } & 14 . & \text { Kyrgyzstan } & 25 . & \text { Serbia } \\ \text { 5. } & \text { Bulgaria } & 15 . & \text { Latvia } & 26 . & \text { Shanghai - China } \\ \text { 6. } & \text { Chinese Taipei } & 16 . & \text { Liechtenstein } & 27 . & \text { Singapore } \\ \text { 7. } & \text { Colombia } & 17 . & \text { Lithuania } & 28 . & \text { Thailand } \\ \text { 8. } & \text { Croatia } & 18 . & \text { Macao - China } & 29 . & \text { Trinidad and } \\ \text { 9. } & \text { Dubai (UAE) } & 19 . & \text { Montenegro } & & \text { Tobago } \\ \text { 10. } & \text { Hong Kong } & 20 . & \text { Panama } & 30 . & \text { Tunisia } \\ & \text { - China } & 21 . & \text { Peru } & 31 . & \text { Uruguay }\end{array}$

\section{Albanian target students in PISA 2000 and PISA 2009}

The first students to take part in PISA 2009 began their first school year in 2000, which was the first year that Albania participated in PISA international assessment. Consequently, a comparison of the results of this period provides important input for further analysis of the impact of reforms and changes in the Albanian education system and the country's educational policies.

Most of the 15-year-old students taking part in PISA 2000 were in the first year of high school.

In 2009, the 15-year-old students who were the target population of PISA assessment were divided into two approximately equal groups; the first half were in the $9^{\text {th }}$ grade, which is the last year of primary education, and the second half belonged to the first year of high school. This change occurred because of a change in the system that increased primary education from 8 to 9 school years, and reduced high school education from 4 to 3 school years.

\section{Relevant Statistics in PISA 2009 - Albania}

Number of 15-year-old students in 2009

55,587 students

Number of 15 -year-old students in the $7^{\text {th }}$ grade and higher 42,767 students Number of students participating in PISA 4,596 students 


\section{Albanian students' performance in PISA 2009}

\section{General view of the results of PISA 2000 and PISA 2009}

Below we present the results of Albanian students in PISA 2000 and PISA 2009 in three domains: reading, mathematics and science.

Table 1: Albania results in PISA 2000 and PISA 2009.

\begin{tabular}{lll}
\hline PISA Albania & PISA 2000 & PISA 2009 \\
\hline Reading & 349 & 385 \\
Mathematics & 381 & 377 \\
Science & 374 & 391 \\
\hline
\end{tabular}

In Figure 2, we provide a graphic presentation of the change in Albanian performance in two PISA assessments in reading, mathematics and science. We can see from the graph that the result of PISA 2009 in reading represents a great improvement ( 36 points) compared to PISA 2000. The reading component was the main domain in both PISA 2009 and PISA 2000. Only one subject is the main domain in every PISA, which means that each subject is the main domain every nine years, or after three PISA assessments. Albania also achieved significant improvement in science (29 points), but the result was not as encouraging in mathematics, which decreased by 4 points.

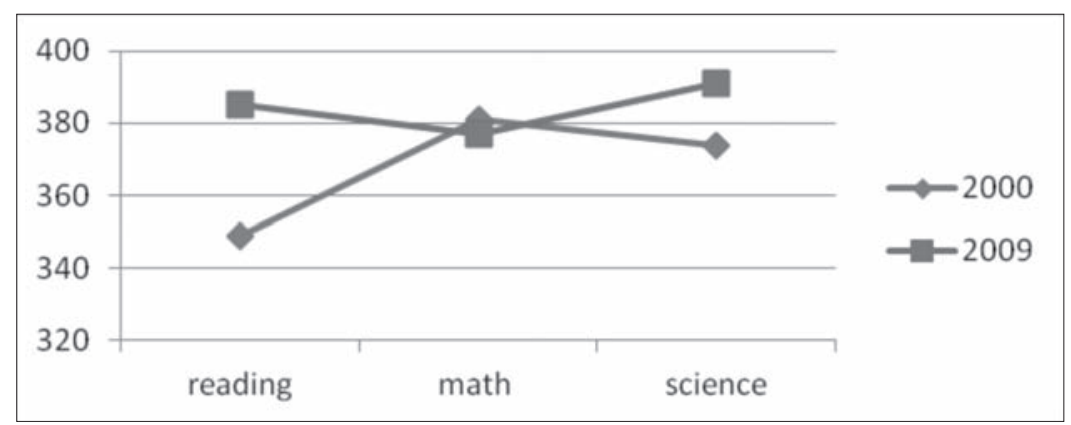

Figure 2: Comparison of Albanian results in PISA 2000 and PISA 2009.

Among the 65 participating countries, Albania was ranked in third place in terms of improvement compared with the results of PISA 2000, with only Chile and Peru achieving a more significant level of improvement. There was an increase of 36 points for all students, which was a considerable change and 
statistically above the OECD average. This change represents a 35 point increase in boys' performance and a 39 point increase in girls' performance. Albania was ranked $60^{\text {th }}$ amongst the 65 participating countries in reading, and achieved $59^{\text {th }}$ place in mathematics and science.

\section{Albanian students' performance by subjects - PISA 2009}

\section{Albania performance in reading in PISA 2009}

\section{Students' performance by levels in reading}

"Since both PISA 2000 and PISA 2009 focused on reading, it is possible to track how student performance in reading changed over that period. Among the 26 OECD countries with comparable results in both assessments, Chile, Israel, Poland, Portugal, Korea, Hungary and Germany as well as the partner countries Peru, Albania, Indonesia, Latvia, Liechtenstein and Brazil all improved their reading performance between 2000 and 2009, while performance declined in Ireland, Sweden, the Czech Republic and Australia" (OECD, 2010e).

Table 2: Albanian students' achievements according to levels.

\begin{tabular}{lcccccccc}
\hline Level of Proficiency & $\begin{array}{r}\text { Below } \\
\text { level } \mathbf{1 b}\end{array}$ & $\begin{array}{c}\text { Level } \\
\mathbf{1 b}\end{array}$ & $\begin{array}{c}\text { Level } \\
\mathbf{1 a}\end{array}$ & $\begin{array}{c}\text { Level } \\
\mathbf{2}\end{array}$ & $\begin{array}{c}\text { Level } \\
\mathbf{3}\end{array}$ & $\begin{array}{c}\text { Level } \\
\mathbf{4}\end{array}$ & $\begin{array}{c}\text { Level } \\
\mathbf{5}\end{array}$ & $\begin{array}{c}\text { Level } \\
\mathbf{6}\end{array}$ \\
\hline Albania & $11.3 \%$ & $18.7 \%$ & $26.6 \%$ & $25.6 \%$ & $14.4 \%$ & $3.1 \%$ & $0.2 \%$ & $\approx 0 \%$ \\
Boys & $17.5 \%$ & $24.4 \%$ & $27.2 \%$ & $19.7 \%$ & $9.7 \%$ & $1.5 \%$ & $\approx 0 \%$ & $\approx 0 \%$ \\
Girls & $4.9 \%$ & $12.8 \%$ & $26.0 \%$ & $31.9 \%$ & $19.4 \%$ & $4.8 \%$ & $0.3 \%$ & $\approx 0 \%$ \\
\hline
\end{tabular}

From Table 2, it is obvious that the achievements of $11.3 \%$ of the students are below Level 1 b, while $43 \%$ are in either Level 2, Level 3 or Level 4 . At the same time, approximately $52 \%$ of the students achieved Level 1a and Level 2, while only approximately $18 \%$ achieved either Level 3, Level 4 or Level 5.

Albania should have had a better percentage of representatives in Level 6. 


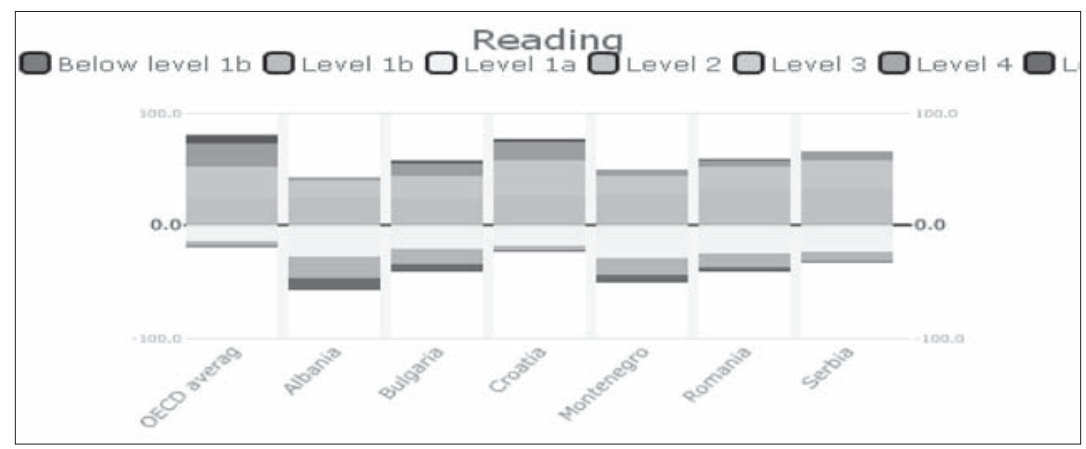

Figure 3: Levels of proficiency in reading in countries in the Albanian region.

\section{Gender differences}

PISA 2009 showed an increase in the disparity between females and males in reading literacy, coupled with a general decline in reading engagement. Female students outperformed males in all participating countries, although the size of the difference varied across countries, with the smallest gap found in Colombia and the largest in Albania.

In PISA 2009 assessment, the achievements of girls were higher than those of boys. Although girls performed better, they were still below the accepted OECD level. Girls gained 417 points, or 62 points more than boys, who achieved 355 points. This difference is statistically significant and equal to approximately one and a half years of education in comparison with the mean scores in one year of education in OECD countries. Even in PISA 2000, there was a clear difference in favour of girls' results. On closer examination, we notice that Albanian girls had higher achievements in Levels 2, 3, 4 and 5 (more than 50\%), clearly indicating that they have more ability than boys. A small percentage of girls even managed to achieve reading ability (skills) at Level 5. Boys also had lower results than girls in the fields of mathematics and science. Differences between boys and girls are closely related to their attitudes and behaviour, so the differences observed would appear to be a social problem rather than a problem of school. As mentioned above, the transition period experienced in Albania after the 1990s was followed by several problems, including difficulties in the education system. The transition process was accompanied by demographic shifts in urban areas in Albania and immigration, resulting in a decrease in interest in education, especially amongst boys, while girls retained a greater level of interest in education, viewing it as an investment in their future. 


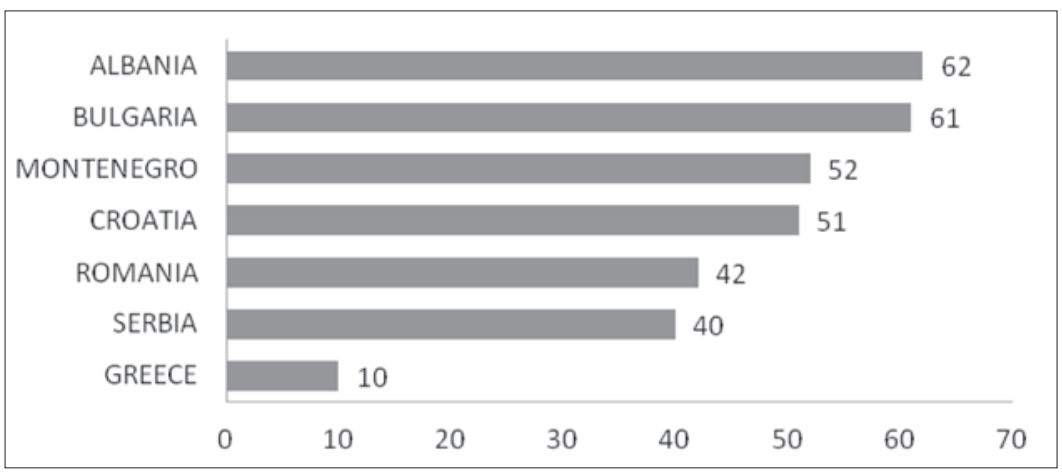

Figure 4: Gender differences (girls-boys) in reading in countries in the Albanian region.

Girls performed better than boys in reading in all of the countries in the Albanian region. As can be seen in Figure 4, the results may be classified into 4 groups:

- $\quad$ Group I - Albania, Bulgaria

- $\quad$ Group II - Montenegro, Croatia

- $\quad$ Group III - Romania, Serbia

- Group IV - Greece
(62 points, 61 points)

(52 points, 51 points)

(42 points, 40 points)

(10 points)

This difference is more evident, and more or less the same, between Albania and Bulgaria, while groups 2 and 3 decreased progressively by 10 points each. Only Greece does not follow the trend of other countries in the Albanian region, with a difference of 10 points.

From this analysis we can conclude that strategies for improvement in boys' abilities in reading should be the focus of education systems in the countries of the Albanian region.

\section{Changes in student performance since 2000}

Based on the results achieved, Albanian students show good or weak achievements in the following aspects:

- Good achievements in reading

- Finding a piece of information in a simple text;

- Comparing information;

- Combining different pieces of information within a text;

- Identifying simple ideas mentioned a couple of times in a given text;

- Interpreting a phrase in a short text or in a known case; 
- Identifying the main idea, or the purpose of the author, in a text that treats a known case;

- Finding the meaning of a phrase or single word;

- Creating a simple relationship between the information given in a text and general knowledge of daily life;

- Explaining the type of the text based on the students' personal experiences and attitudes.

- $\quad$ Serious weaknesses in reading

- Confrontation with types of texts unfamiliar to the students;

- Integrating information obtained from different texts;

- Identifying ideas previously unknown;

- Generating abstract categories for developing different interpretations;

- Critical evaluation of a complex text about an unknown case;

- Applying sophisticated comprehension beyond the text;

- Critical evaluation of different texts and forming a hypothesis on them, thus developing specialised knowledge and processing concepts that can be contrary to what is expected.

- Improvements in reading performance were achieved at all proficiency levels

"Chile and the partner countries Indonesia, Albania and Peru showed improvements in reading performance among students at all proficiency levels. ... These countries are also among those that show the largest improvement in mean performance and in which the percentage of students performing below Level 2 decreased" (OECD, 2010e). The lowest achieving students show similar levels of improvement to the highest achieving students in Albania.

- $\quad$ Enjoyment of reading increased

"In a large number of countries, the decrease in enjoyment of reading was much more pronounced among boys than among girls, leading to a widening of the gender gap. Poland and the partner country Albania saw the largest increase in the gender gap in enjoyment of reading. In Albania, girls' enjoyment of reading increased between 2000 and 2009 , but on average in 2009, boys enjoyed reading as much as they did in 2000."

- The share of girls reading for enjoyment increased

The proportion of girls who reported reading for enjoyment increased 
in some countries in the Albanian region, exceeding 80\% in Greece, Bulgaria and Albania.

- Improvement is possible regardless of a country's cultural context or its starting position

"Among the 26 OECD countries with comparable results in both assessments, Chile, Germany, Hungary, Israel, Korea, Poland, Portugal, and the partner countries Albania, Brazil, Indonesia, Latvia, Liechtenstein and Peru all show overall improvements in reading performance. The fact that such a diverse group of countries succeeded in raising the level of their students' performance in reading indicates that improvement is possible regardless of a country's cultural context or where it starts out from" (OECD, 2011a).

\section{Reading performance by school location in Albania}

Students in city schools in Albania perform much better than students in rural schools.

On average across the OECD, students in city schools outperform students in rural schools by 40 score points, or the equivalent of one year of education.

Table 3: Reading performance by school location.

\begin{tabular}{|c|c|c|c|c|}
\hline $\begin{array}{l}\text { Reading } \\
\text { performance } \\
\text { by school } \\
\text { location }\end{array}$ & $\begin{array}{l}\text { Students attending } \\
\text { schools } \\
\text { located in a vil- } \\
\text { lage, hamlet or } \\
\text { rural area } \\
\text { (fewer than } \\
3,000 \text { inhabitants) }\end{array}$ & $\begin{array}{l}\text { Students attending } \\
\text { schools located } \\
\text { in a } \\
\text { small town } \\
\text { (from } 3,000 \text { to } \\
\text { approx. } 15,000 \\
\text { inhabitants) }\end{array}$ & $\begin{array}{l}\text { Students attending } \\
\text { schools located in } \\
\text { a town } \\
\text { (from } 15,000 \text { to } \\
\text { approx. } \\
100,000 \text { inhabit- } \\
\text { ants) }\end{array}$ & $\begin{array}{l}\text { Students attending } \\
\text { schools located in } \\
\text { a city } \\
\text { (from } 100,000 \text { to } \\
\text { approx. } \\
1,000,000 \text { inhabit- } \\
\text { ants) }\end{array}$ \\
\hline $\begin{array}{l}\text { Percentage of } \\
\text { students }\end{array}$ & $25 \%$ & $20 \%$ & $27.7 \%$ & $27.3 \%$ \\
\hline $\begin{array}{l}\text { Average } \\
\text { performance } \\
\text { in reading }\end{array}$ & 347 & 368 & 394 & 426 \\
\hline
\end{tabular}

The results show a progressive increase in the case of schools in a location with a greater number of inhabitants. It seems that in urban areas with a greater number of inhabitants there is more possibility of guaranteeing a better education system.

“...in Turkey, the Slovak Republic, Chile, Mexico and Italy as well as the partner countries Peru, Tunisia, Albania, Argentina and Romania, 
the performance gap between students in city schools and those in rural schools is more than 45 score points, after accounting for students' socio-economic background. This gap is 80 score points or more - or the equivalent of two years of schooling - in Hungary and in the partner countries Bulgaria, Kyrgyzstan and Panama." (OECD, 2010b, p. 14).

\section{Albanian performance in mathematics in PISA 2009}

\section{Mathematics performance by levels}

The percentage of students with low achievements is too high, with $40.5 \%$ of students falling below Level 1, while 30\% of students are in Level 2, Level 3 or Level 4 . There are more boys than girls below Level 1 and more girls than boys in Level 1 or Level 2, while the same percentage of boys and girls are in Level 3 or Level 4 . There are more boys than girls in Level 5

Table 4: Albanian students' performance by levels in mathematics.

\begin{tabular}{l|c|c|c|c|c|c|c}
\hline $\begin{array}{l}\text { Level of } \\
\text { Proficiency }\end{array}$ & $\begin{array}{c}\text { Below } \\
\text { Level 1 }\end{array}$ & Level 1 & Level 2 & Level 3 & Level 4 & Level 5 & Level 6 \\
\hline Albania & $40.5 \%$ & $27.2 \%$ & $20.2 \%$ & $9.1 \%$ & $2.6 \%$ & $0.4 \%$ & $\approx 0 \%$ \\
Boys & $43.5 \%$ & $25.5 \%$ & $18.8 \%$ & $9 \%$ & $2.6 \%$ & $0.5 \%$ & $\approx 0 \%$ \\
\hline Girls & $37.3 \%$ & $29 \%$ & $21.6 \%$ & $9.1 \%$ & $2.7 \%$ & $0.3 \%$ & $\approx 0 \%$ \\
\hline
\end{tabular}

\section{Levels of proficiency in countries in the Albanian region}

The percentage of students below Level 1 is higher than the OECD mean score below Level 1 for all countries in the Albanian region. 


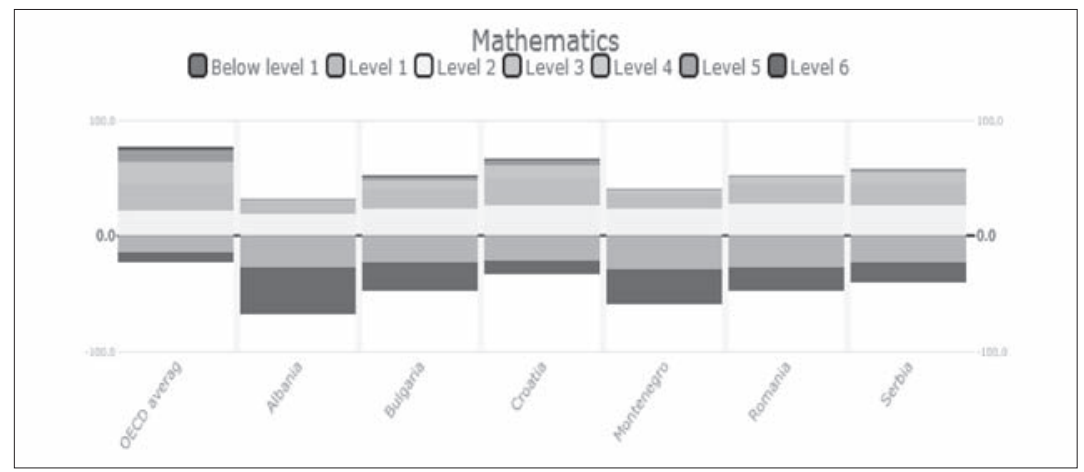

Figure 5: Levels of proficiency in mathematics in countries in the Albanian region.

Gender differences in mathematics performance in countries in the Albanian region

In Albania, girls outperformed boys by 11 score points. In fact, Albania and Bulgaria are the only countries in the region in which girls outperform boys in mathematics. On average across OECD countries, boys outperform girls by 12 score points.

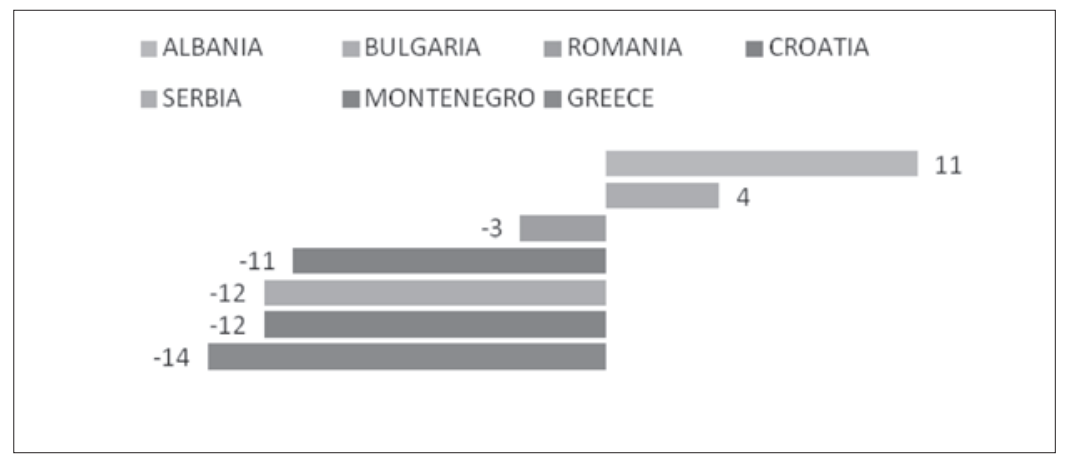

Figure 6: Gender differences (girls-boys) in mathematics in countries in the Albanian region. 


\section{Albanian performance in science in PISA 2009}

\section{Science performance by levels}

Assessment in science includes assessment in a group of school subjects such as chemistry, biology, physics, geography, and Earth science. Albania achieved 391 points from a possible 575 points.

Table 5: Albanian students' performance by levels in science in PISA 2009.

\begin{tabular}{lccccccc}
\hline $\begin{array}{l}\text { Level of } \\
\text { Proficiency }\end{array}$ & $\begin{array}{c}\text { Below } \\
\text { Level 1 }\end{array}$ & Level 1 & Level 2 & Level 3 & Level 4 & Level 5 & Level 6 \\
\hline Albania & $26.3 \%$ & $31 \%$ & $27.7 \%$ & $12.9 \%$ & $2.0 \%$ & $0.1 \%$ & $\approx 0 \%$ \\
Boys & $32 \%$ & $32 \%$ & $24 \%$ & $10.3 \%$ & $1.6 \%$ & $0.1 \%$ & $\approx 0 \%$ \\
Girls & $20.3 \%$ & $30 \%$ & $31.5 \%$ & $15.7 \%$ & $2.5 \%$ & $0.1 \%$ & $\approx 0 \%$ \\
\hline
\end{tabular}

$26.3 \%$ of students are below Level 1, while $43 \%$ of students are in Level 2, Level 3 or Level 4 , with the percentage of girls in these levels being about $50 \%$ and the percentage of boys being $36 \%$. There is a much higher percentage of boys than girls below Level 1.

\section{Levels of proficiency in some countries in the Albanian region}

In Romania, Serbia, Montenegro and Albania, the percentage of students who reach Level 6 is almost o\%.

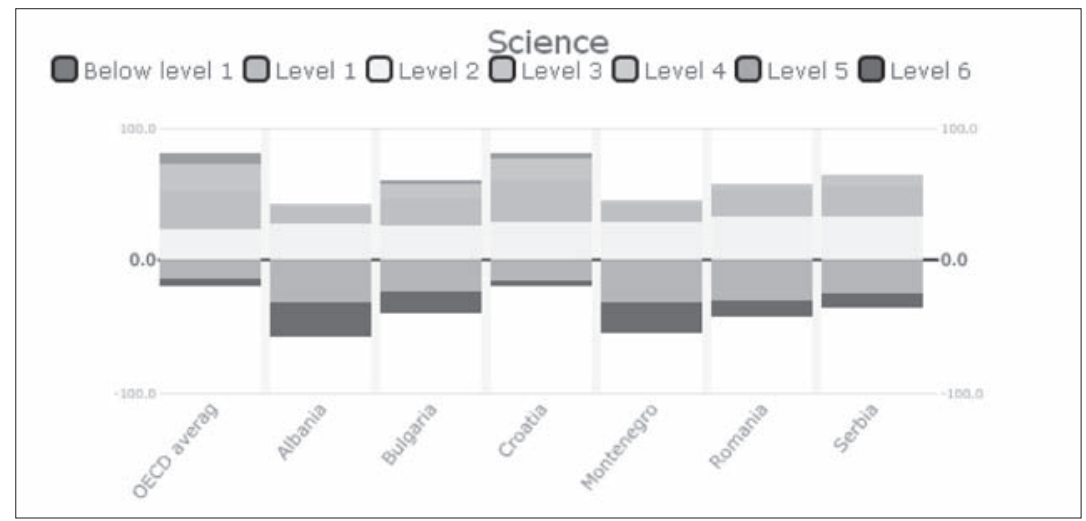

Figure 7: Levels of proficiency in countries in the Albanian region. 
Across OECD countries, $8.5 \%$ of students are proficient at Levels 5 or 6 . The countries with $0.5 \%$ or less of students at these levels are Albania (0.1\%), Montenegro (0.2\%) and Romania (0.4\%).

Across OECD countries, an average of $29.1 \%$ of students are proficient at Level 4 or higher.

In contrast, less than $5 \%$ of students reach Level 4, 5 or 6 in Albania (2.1\%), Montenegro (3.4\%), and Romania (4.8\%). Croatia has the lowest percentage of students below Level 1, while Albania and Montenegro have the greatest percentage of students below Level 1.

\section{Girls perform better than boys in science in some countries in the Albanian region}

In Albania, girls perform better than boys in all three subjects of PISA assessment. In science, this difference is 29 points more than boys, with boys gaining approximately 377 points and girls 406 points. In Figure 8, we show this indicator for the countries of the Albanian region. Girls outperform boys in all of the countries of the Albanian region. The highest difference is in Albania and the lowest is in Serbia. Greece, Romania and Croatia have statistically the same difference.

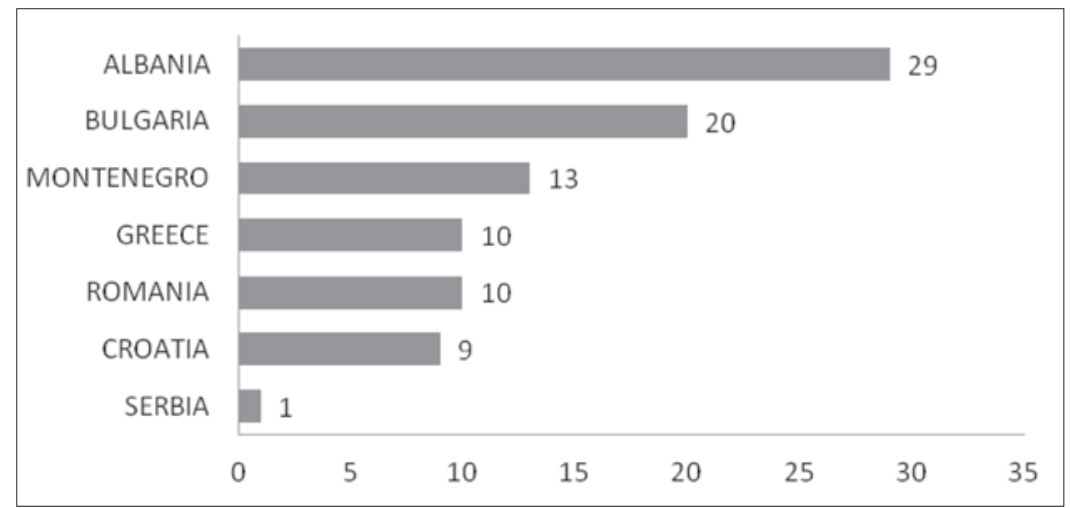

Figure 8: Gender differences (girls-boys) in performance in science in countries in the Albanian region. 
Difficulties faced by Albanian students in science:

- In questions in the science part of PISA 2009 assessment, there was a combination of knowledge from different subjects. This made it difficult for Albanian students to give exact answers, as the Albanian curricula did not treat exercises of this question type. Some of this knowledge has become part of curricula since PISA 2009 was developed.

- Albanian students had difficulties in evaluating and reaching conclusions in non-standard situations. It seems that describing and reproducing knowledge dominates reasoning, interpreting and arguing. Teacher training is therefore needed in order to provide students with combined knowledge not only in one subject, but in a group of subjects. However, this lack of knowledge does not occur only due to a lack of teacher qualification, but often also due to a lack of didactic and experimental equipment, as well as a lack of contemporary information and examples from daily life in Albanian school curricular classes or in Albanian extracurricular classes.

- It is difficult for Albanian students to solve problems from their textbooks. This is partly due to the reasons mentioned above, but also due to insufficient use of other information sources typically offered by new technology, such as the Internet and scientific publications aimed at this age group.

\section{Performance in reading, mathematics and science by type of school}

According to data analysis on the three domains of assessment, private schools achieved higher results. The best result was achieved in reading, with the difference in mean score of 65 points being more than one school year in OECD countries, as shown in Table 6.

Some of the factors that affect the higher performance results of private schools are:

- As a consequence of the socioeconomic problems that Albania faced during the transition period, public education encountered a lot of difficulties, thus giving private education an advantage as an alternative.

- $\quad$ Private schools are located in the country's main cities.

- The number of students per class in private schools is lower than in public schools.

- The private education system has more autonomy than the public system. 
Table 6: Performance of students in the three domains by type of school.

\begin{tabular}{ccccc}
\hline \multicolumn{4}{c}{ State schools vs. independent private schools ${ }^{1}$} \\
\hline $\begin{array}{c}\text { Percentage } \\
\text { of students }\end{array}$ & $\begin{array}{c}\text { Performance } \\
\text { in reading } \\
\text { (mean score) }\end{array}$ & $\begin{array}{c}\text { Performance } \\
\text { in mathematics } \\
\text { (mean score) }\end{array}$ & $\begin{array}{c}\text { Performance } \\
\text { in science } \\
\text { (mean score) }\end{array}$ & $\begin{array}{c}\text { Difference in the perfor- } \\
\text { mance on the reading } \\
\text { scale between public and } \\
\text { private schools. Differ- } \\
\text { ence (Public - Private) }\end{array}$ \\
\hline $\mathbf{1 1 . 1}$ & 442 & 426 & 445 & -65 \\
\hline
\end{tabular}

\section{Other aspects of Albanian results in PISA 2009}

\section{Teacher-student relations in PISA 2000 and 2009}

The following graph shows the percentages of students agreeing or strongly agreeing that "Most of my teachers really listen to what I have to say".

It is evident that in Albania, more than in other countries, students report their teachers' willingness to listen to them and to help them.

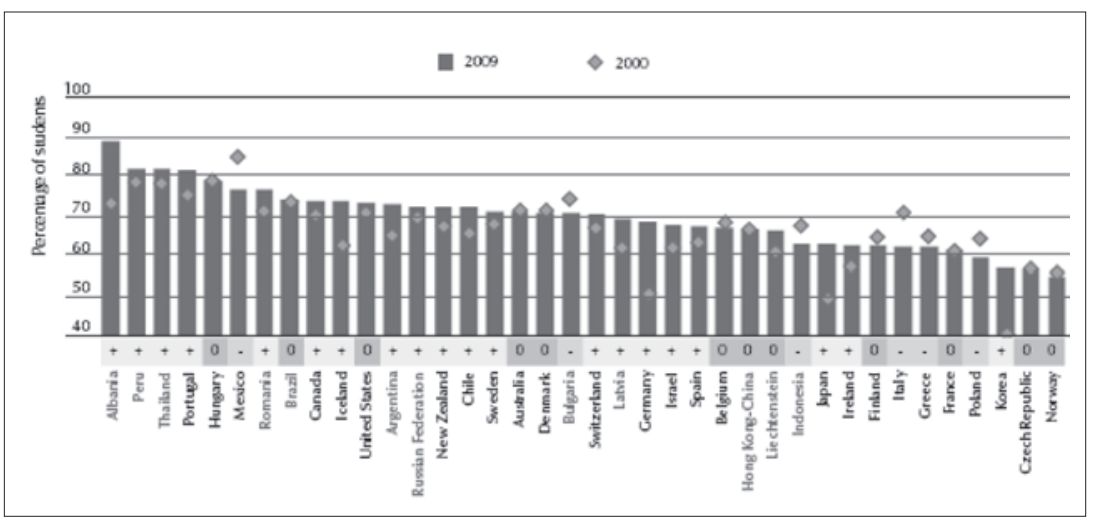

Figure 9: The percentage of students agreeing/strongly agreeing that "Most of my teachers really listen to what I have to say."

It is evident that in Albania there is a trusting climate between teachers and students. This is a strong base from which those involved in education in Albania can start to increase the level of students' achievements in future national and international assessments. "Among partner countries and economies, teachers' role in stimulating interest in reading follows a similar pattern to that of OECD countries. The highest levels of the index of teacher stimulation of 
students' reading engagement are observed in Kazakhstan, the Russian Federation, Kyrgyzstan, Azerbaijan, Montenegro and Albania” (OECD, 2010d).

\section{Classroom discipline in PISA 2000 and 2009}

This indicator improved from 2000 to 2009 in many countries participating in PISA evaluation.

"Students who reported that there are few disciplinary problems in their classes perform better in PISA than those who reported that a lack of discipline in class disrupts learning.

- Between 2000 and 2009 classroom discipline improved in many countries that participate in PISA, and the majority of students in OECD countries enjoy orderly lessons.

- Generally, countries where discipline in the classroom improved between 2000 and 2009 are also those where students reported better relations with their teachers.

PISA offers no evidence to support the notion that discipline in school is a growing problem and that students are becoming progressively more disengaged from school. In fact, between 2000 and 2009 discipline in school and teacher-student relations improved" (OECD, 2011b).

\section{The impact of the socioeconomic environment}

The impact of the socioeconomic environment on assessment results was lower in 2009 than in 2000. Thus we can conclude that Albania still has potential resources for improving the achievements of Albanian students that are not related to socioeconomic resources.

PISA 2009 results show that the impact of a student's socioeconomic background on his or her performance has weakened significantly in Albania.

"Among countries that showed improvements in reading performance, changes in the demographic and socioeconomic composition of student populations had the largest impact in Israel and the partner country Albania, where the improvement in student performance would have been seven and 12 score points larger, respectively, if the demographic and socioeconomic context had been similar in 2000 and 2009" (OECD, 2010a).

The largest decline in the socioeconomic background of students between 2000 and 2009 was observed in Albania and Bulgaria. 


\section{Performance of students with an immigrant background in the host country by country of origin}

Albanian students in host countries had lower achievments than students of the host country. Albanian students in Montenegro had the lowest achivements and those in Greece had the highest achivements in relation to the achivement of the host country.

Table 7: Albanian students' performance in host countries.

\begin{tabular}{lccc}
\hline Albanian students in host countries & Switzerland & Greece & Montenegro \\
\hline Mean of the country & 501 & 483 & 401 \\
Students from Albania & 384 & 439 & 373 \\
\hline
\end{tabular}

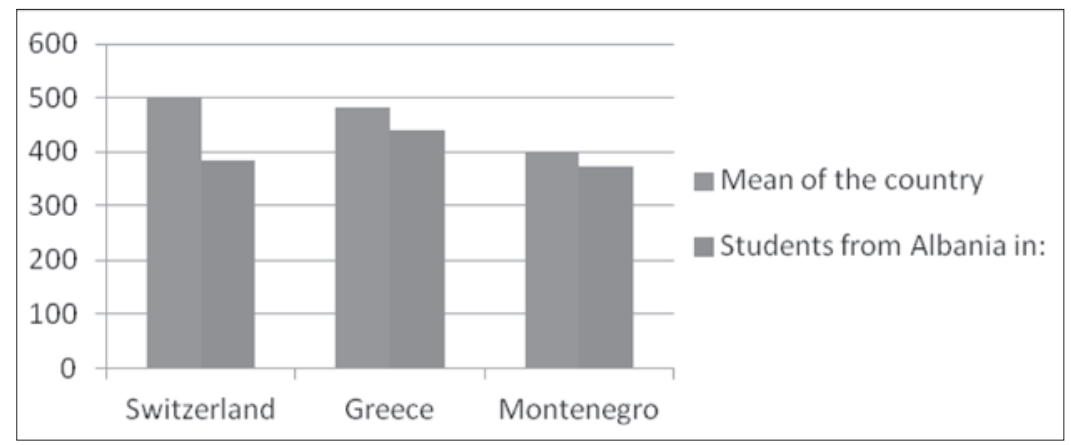

Figure 10: Graph of Albanian student performance in host countries.

\section{Pre-primary school attendance improves student performance}

It is clear that children who have attended kindergarten, which offers preschool education in Albania, have higher results. Same correlation is also identified for other countries participating in PISA 2009. 
Table 8: Performance according to pre-primary school attendance.

\begin{tabular}{lccc}
\hline $\begin{array}{l}\text { Performance by pre-primary } \\
\text { school attendance }\end{array}$ & $\begin{array}{c}\text { No pre-primary } \\
\text { school attendance }\end{array}$ & $\begin{array}{c}\text { Pre-primary school } \\
\text { attendance for one } \\
\text { year or less }\end{array}$ & $\begin{array}{c}\text { Pre-primary school } \\
\text { attendance for more } \\
\text { than one year }\end{array}$ \\
\hline Percentage of students & 24.5 & 22.7 & 52.7 \\
$\begin{array}{l}\text { Average performance in } \\
\text { reading }\end{array}$ & 371 & 385 & 404 \\
\hline
\end{tabular}

- 15-year-old students who have attended pre-primary education perform better in PISA than those who have not, even after accounting for their socioeconomic backgrounds.

- Disadvantaged students have less access to pre-primary education than advantaged students in almost every country, particularly those in which pre-primary education is not widespread.

- High-performing and equitable school systems are also those with little socioeconomic disparity in access to pre-primary education.

- How pre-primary education is provided affects the extent to which attendance benefits individual students.

Widening access to pre-primary education can improve both overall performance and equity by reducing socioeconomic disparities among students, if extending coverage does not compromise quality.

\section{The most important factors in PISA 2009 results}

\section{Socioeconomic variations}

During the years 1990-1999, the overall socioeconomic development in Albania underwent huge changes. The effect of this was evident even in the results that students achieved in PISA 2000. Over the subsequent ten years, Albania achieved encouraging socioeconomic growth and stability. The positive effects of this were again seen in students' results in PISA 2009. Consequently, we can see that in Albania socioeconomic development is the most important factor in the level of educational results. This argument becomes even more convincing if we examine the progress in reading results, which were not only higher but were almost in same level for both boys and girls.

Before 1990, more than $60 \%$ of the population of Albania lived in rural areas. In 1990, the political and economic regime in Albania changed, resulting in a freeing up of the demographic movement and an orientation of the population towards urban areas. As can be observed in the figures shown in Table 3, 
students' results are higher in schools located in urban areas.

\section{Education system reforms}

Since 1990, many changes have taken place in the Albanian education system, especially in the pre-university system. In order to improve the quality of education for preschool children making the transition from kindergarten to elementary school, new educational programmes and methods have recently been introduced. The curricula of the elementary education system were the first affected by the changes, mainly in terms of textbooks and educational programmes. These programmes aim to use interactive teaching methodology in elementary school. Teachers in the Albanian education system have attended continuous training modules on these programmes for several years and are now implementing them successfully.

Changes and improvements have occurred in the main fields of educations in the form of: managing and financial administration, curricular programmes, school textbooks, the external and internal evaluation system, new didactic technologies, etc.

\section{Recommendations on educational policy by subjects}

\section{Reading}

The actual curricula in reading seem to be more suitable for students with high results. The plan for overall comprehensive curricula is really essential. Certain parts of the curricula should be relieved from overburdening; these are key parts of the curricula that transmit numerous concepts at the same time, making the intelligibility of these concepts more difficult for students. The reading part of the programme is mainly taken up by fiction, and little scope remains for other kinds of literature or for so-called informative, descriptive literature, etc. However, it is a well known fact that fiction is often regarded by students as difficult, firstly due to the nature of the topics and secondly because in some cases it is not selected in accordance with students' age. Furthermore, there is not enough space for other kinds of literature that are nowadays often encountered by the students themselves, such as reading informative texts, reports, advertisements, etc.

\section{Mathematics}

Comparison of the mathematics results in Pisa 2000 and 2009 showed a decrease of 4 points. In view of the evident improvement in reading and science results, the results in mathematics are cause for concern. It is obvious that the 
improvement of curricula is more essential than other factors that might have affected in this result.

Programmes and textbooks should be improved, as there are some aspects of mathematics that are not included as much as necessary. Geometry and graphical presentations should be more comprehensive and integrated into the subject programme of mathematics. Educational textbooks and programmes should allow new and difficult concepts to be treated longer in class.

The transition of the existing $9^{\text {th }}$ grade of primary education to high school is not properly reflected in the respective programmes and textbooks. In order to guarantee the required progress, this transition should be associated with the necessary scientific and didactic qualifications of mathematics teachers.

The result of students with the lowest achievements must be improved, as the percentage of such students is unacceptably high, with $40.5 \%$ of students achieving results below Level 1 (Table 4).

The results of national exams at the end of the $9^{\text {th }}$ grade must be analysed more deeply and compared with the results obtained from PISA assessments. In the national exam of mathematics at the end of gth grade, $75 \%$ of students gained less than half of the maximum points.

Data provided by national assessments must be examined further in order for important conclusions to be reached, thus making the comparison of these results with those of international assessments more effective.

\section{Science}

In the curriculum of the nine-year school system, knowledge for a group of subjects, such as chemistry, biology, physics, geography, etc., should be integrated. Furthermore, the basic required logistics should be organised, such as equipment and labs that in most cases are mandatory for this subject, and the use of new information technology should be encouraged.

Not all students have the possibility of obtaining this kind of information individually. In school environments, such as libraries and Internet rooms (centres of knowledge development), there should be teachers who can support students in expanding their knowledge.

Instead of the traditional lecturing method, teachers should practise new methods putting the students at the lesson focus, thus giving priority to student discussion and ways of thinking and reasoning.

In general, teacher training should be continuous and effective. Training activities must be more effective in each of the three subjects, because often there is no continuity and training is not related to the curriculum being 
implemented. The qualification of teachers of grades 6-9 should be the main focus.

"When it comes to learning, it's the quality of teaching at school and students' attitudes towards learning that count most, not the number of hours students spend studying" (OECD, 2011c).

\section{Improvement of low student achievements in reading, mathematics and science}

In most countries, students who are poor performers are mainly boys from socioeconomically disadvantaged backgrounds. Results from PISA indicate that this group is far from being equipped with the skills and competencies needed to participate fully in society.

The achievements of students with low results should be improved due to the fact that the percentage of such students is very high. Furthermore, the factors affecting this result should be identified. Some of these factors have been mentioned above; however, we should highlight the fact that finding ways to motivate reading, especially in boys, and focusing increased attention on social groups with socioeconomic difficulties, still remain the key factors.

In many countries, progress was made towards achieving greater equality in learning outcomes during the 2000-2009 period.

"Improvements among the lowest performing students do not have to be realised at the expense of the highest performing students... In none of the countries where the lowest performing students improved did the highest performing students show a decline in their performance" (OECD, 2011a).

\section{PISA RESULTS SUGGEST HOW COUNTRIES CAN IMPROVE}

\section{THEIR PERFORMANCE.}

"PISA results suggest that the countries that improved the most, or that are among the top performers, are those that establish clear, ambitious policy goals, monitor student performance, grant greater autonomy to individual schools, offer the same curriculum to all 15 -year-olds, invest in teacher preparation and development, and support low performing schools and students" (OECD, 2011a). 


\section{References}

Evaluation of Students' Achievements (2007). National Agency of Evaluation of Students'

Achievements (AVA), Albania.

Evaluation of Students' Achievements (2008). National Agency of Evaluation of Students'

Achievements (AVA), Albania.

Improvement of Teacher Qualifications (2009). Tiranë: Institute of Curricula and Training (IKT).

Ministry of Albanian Education (2011). Conference of Albanian PISA 2009 Results.

Report of State Matura of Albania 2007, 2008, 2009, 2010. National Agency of Evaluation of Students

Achievements (AVA), Albania.

OECD (2010a). PISA 2009 Results: What Students Know and Can Do - Student Performance in

Reading, Mathematic and Science, OECD Publishing, (Volume I). Retreived from http://dx.doi.

org/10.1787/9789264091450-en.

OECD (2010b). PISA 2009 Results: Overcoming Social Background - Equity in Learning

Opportunities and Outcomes (Volume II). OECD Publishing. Retreived form http://dx.doi.

org/10.1787/9789264091504-en.

OECD (2010c). PISA 2009 Results: Learning to Learn (Volume III). OECD Publishing.

OECD (2010d). PISA 2009 Results: What Makes a School Successful (Volume IV). OECD Publishing.

OECD (2010e). PISA 2009 Results: Learning Trends- Changes in Student Performance since 2000

(Volume V). OECD Publishing.

OECD (2011a). All countries can improve their students' reading performance. PISA in Focus, (2,

March).

OECD (2011b). Has discipline in school deteriorated? PISA in Focus, (4, May).

OECD (2011c). Does investing in after-school classes pay off?. PISA IN Focus, (3, April).

The Student Evaluation Standards (2003). California, USA: Corwin Press, Inc..

\section{Biographical note}

Alfons Harizaj has been first graduated in Mathematics nearby Faculty of Natural Sciences, from Tirana University, after in Post Graduated Studies for Advanced Education and Administrative Management and lately Master for Advanced Numerical Analysis. Through his carrier he has useful experience as expert, researcher and manager in standardized national assessments and examinations. On last three years he is Head of Assessment nearby National Agency of Exams and in the same time National Project Manager of PISA 2009 and 2012, Albania. 